\title{
Effect of abomasal infusion of oligofructose on portal-drained visceral ammonia and urea-nitrogen fluxes in lactating Holstein cows
}

\author{
B. A. Røjen, ${ }^{1}$ M. Larsen, and N. B. Kristensen ${ }^{2}$ \\ Department of Animal Science, Aarhus University, Foulum, DK-8830 Tjele, Denmark
}

\begin{abstract}
The effects of abomasal infusion of oligofructose in lactating dairy cows on the relationship between hindgut fermentation and $\mathrm{N}$ metabolism, and its effects on $\mathrm{NH}_{3}$ absorption and transfer of blood urea- $\mathrm{N}$ across the portal-drained viscera versus ruminal epithelia were investigated. Nine lactating Holstein cows fitted with ruminal cannulas and permanent indwelling catheters in major splanchnic blood vessels were used in an unbalanced crossover design with 14 -d periods. Treatments were continuous abomasal infusion of water or $1,500 \mathrm{~g} / \mathrm{d}$ of oligofructose. The same basal diet was fed with both treatments. Eight sample sets of arterial, portal, hepatic, and ruminal vein blood, ruminal fluid, and urine were obtained at $0.5 \mathrm{~h}$ before the morning feeding and at $0.5,1.5,2.5,3.5,4.5,5.5$, and $6.5 \mathrm{~h}$ after feeding. It was hypothesized that an increased supply of fermentable substrate to the hindgut would increase the uptake of urea- $\mathrm{N}$ from blood to the hindgut at the expense of urea-N uptake to the forestomach. The study showed that abomasal oligofructose infusion decreased the total amount of urea- $\mathrm{N}$ transferred from the blood to the gut, $\mathrm{NH}_{3}$ absorption, and arterial blood urea- $\mathrm{N}$ concentration. Subsequently, hepatic $\mathrm{NH}_{3}$ uptake and urea-N production also decreased with oligofructose infusion. Additionally, urea- $\mathrm{N}$ concentration in milk and urinary $\mathrm{N}$ excretion decreased with oligofructose treatment. The oligofructose infusion did not affect ruminal $\mathrm{NH}_{3}$ concentrations or any other ruminal variables, nor did it affect ruminal venous - arterial concentration differences for urea- $\mathrm{N}$ and $\mathrm{NH}_{3}$. The oligofructose treatment did not affect milk yield, but did decrease apparent digestibility of OM, N, and starch. Nitrogen excreted in the feces was greater with the oligofructose infusion. In conclusion, the present data suggest that increased hindgut fermentation did not upregulate urea- $\mathrm{N}$ transfer to the hindgut at the expense of urea-
\end{abstract}

\footnotetext{
Received March 22, 2012.

Accepted July 22, 2012.

${ }^{1}$ Corresponding author: betina.amdisenrojen@agrsci.dk

${ }^{2}$ Current address: Syddansk Kvæg, Billundvej 3, DK-6500 Billund, Denmark.
}

$\mathrm{N}$ uptake by the rumen, and the observed reduction in arterial blood urea- $\mathrm{N}$ concentration appeared not to be due to increased urea-N transport, but rather could be explained by reduced $\mathrm{NH}_{3}$ input to hepatic urea- $\mathrm{N}$ synthesis caused by increased sequestration of $\mathrm{NH}_{3}$ in the hindgut and excretion in feces. Increasing the hindgut fermentation in lactating dairy cows by abomasal infusion of $1,500 \mathrm{~g} / \mathrm{d}$ of oligofructose shifted some $\mathrm{N}$ excretion from the urine to feces and possibly reduced manure $\mathrm{NH}_{3}$ volatilization without impairing rumen fermentation.

Key words: oligofructose, urea-nitrogen recycling, ammonia absorption, hindgut fermentation

\section{INTRODUCTION}

The environmental impact of $\mathrm{N}$ from intensive dairy production systems is a matter of great concern. Urea-N is the most abundant component of urinary $\mathrm{N}$ (Bristow et al., 1992) and is rapidly converted to $\mathrm{NH}_{3}$ by microbial urease. In comparison, fecal $\mathrm{N}$ originates from indigestible feed, endogenous, and microbial protein, which is more slowly degraded to $\mathrm{NH}_{3}$. Increasing carbohydrate fermentation in the hindgut has been found to increase fecal $\mathrm{N}$ excretion, decrease urinary $\mathrm{N}$ excretion, and decrease blood urea-N concentration (Thornton et al., 1970; Gressley and Armentano, 2005). These effects are the result of sequestration of $\mathrm{N}$ in microbial matter excreted in the feces of ruminants (Ørskov et al., 1970; Surra et al., 1997). These effects have also been shown in monogastrics, including humans (Levrat et al., 1993; Younes et al., 2001, 2006). In humans, the observed effect of stimulating the extrarenal route of $\mathrm{N}$ excretion through the digestive route may aid in alleviating chronic renal failure and may decrease uremia without the nutritional drawbacks of restrictive protein diets (Younes et al., 2001, 2006). From studies mainly with monogastrics, the general agreement appears to be an association between increased transfer of blood urea- $\mathrm{N}$ to the hindgut and carbohydrate fermentation, which leads to a more effective microbial proliferation and thus enhances the fecal excretion of microbial $\mathrm{N}$ (Rémésy and Demigné, 1989; Hesta et al., 2001; Younes et al., 2006). Shifting some N excretion from the urine 
to feces in dairy cows by increasing hindgut fermentation without jeopardizing ruminal microbial protein synthesis may prove beneficial in terms of the environmental stability of $\mathrm{N}$ in manure. Dietary carbohydrates of plant origin, known as fructans, especially inulin and oligofructose, which are resistant to hydrolysis by digestive enzymes but fermented by ruminal and colonic microorganisms (Roberfroid and Delzenne, 1998; Kaur and Gupta, 2002), may exert potential beneficial effects related to hindgut fermentation.

In dairy cattle, decreasing the $\mathrm{N}$ status by dietary interventions has not been found to increase urea-N transport from the blood to the rumen and portal-drained visceral (PDV) tissues when expressed in absolute amounts, but if anything, a trend exists toward greater urea- $\mathrm{N}$ transport with increasing $\mathrm{N}$ intake (Calsamiglia et al., 2010; Røjen et al., 2011; Røjen and Kristensen, 2012). This contradicts the recycling theorem, namely, that a reduction in $\mathrm{N}$ intake (or arterial urea- $\mathrm{N}$ concentration) will increase the potential of the cow to recycle urea- $\mathrm{N}$ to the rumen and decrease urinary urea$\mathrm{N}$ excretion, and will thereby be able to compensate for a reduction in $\mathrm{N}$ intake without negative effects on production performance. Urea- $\mathrm{N}$ recycling, when expressed as a proportion of hepatic urea- $\mathrm{N}$ synthesis (or $\mathrm{N}$ intake), increases with decreasing $\mathrm{N}$ intake (Lapierre and Lobley, 2001); however, this does not translate into an increase in the absolute amount of urea- $\mathrm{N}$ transported across the PDV. Similarly, the extraction of arterial urea- $\mathrm{N}$ across the rumen epithelia is upregulated with decreasing $\mathrm{N}$ intake, indicating that the permeability to urea- $\mathrm{N}$ across the rumen is increased; however, the permeability is not upregulated enough to compensate for the reduction in $\mathrm{N}$ intake, and production performance cannot be sustained (Røjen et al., 2011). Thus, the potential for urea-N recycling to compensate for reduced $\mathrm{N}$ intake to improve $\mathrm{N}$ utilization seems limited. Of the total urea-N removal from the blood across the PDV in cattle, the forestomach accounts for a large proportion (Theurer et al., 2002), and in growing pigs, the uptake of arterial urea- $\mathrm{N}$ by the PDV tissues was found to be very low (Kristensen et al., 2009). These observations led us to question whether a change in PDV urea-N uptake is the actual causative link between changes in hindgut fermentation and $\mathrm{N}$ metabolism. To our knowledge, data on the relationship between urea- $\mathrm{N}$ transport to the gut tissues and hindgut fermentation in ruminants is scarce; thus, an experiment was conducted to investigate whether changes in $\mathrm{NH}_{3}$ absorption or changes in urea- $\mathrm{N}$ transfer from the blood to the gut tissues were affected by abomasal oligofructose infusion in lactating Holstein cows. We hypothesized that an increased supply of fermentable substrate to the hind- gut would increase the uptake of urea- $\mathrm{N}$ from the blood to the hindgut at the expense of urea- $\mathrm{N}$ uptake to the forestomach.

\section{MATERIALS AND METHODS}

The present experiment complied with the Danish Ministry of Justice Law No. 382 (June 10, 1987), Act No. 726 (September 9, 1993), concerning experiments with animals and care of experimental animals.

\section{Animals and Feeding}

Nine second-parity Danish Holstein cows were implanted with a ruminal cannula and permanent indwelling catheters in an artery, mesenteric vein, hepatic portal vein, hepatic vein, and right ruminal vein prepartum, as described previously (Kristensen et al., 2007, 2010; Larsen and Kristensen, 2009). Cows in the present study were $102 \pm 1$ DIM and weighed $571 \pm 48 \mathrm{~kg}$ at the first experimental sampling day. Cows were randomly allocated to 2 experimental diets in a crossover design (balanced for 8 cows) with 14-d periods. The dietary treatments were continuous abomasal infusion of water (CTRL) or 1,500 g/d of oligofructose (OLIGO). An abomasal infusion device was constructed and placed in the abomasum via the ruminal cannula (Larsen and Kristensen, 2009). The OLIGO infusate was prepared daily as a $15 \%$ solution of oligofructose (Orafti P95, Alisano, Birkerød, Denmark) using cold tap water and a mixer wagon for milk replacer. Infusates were infused at a rate of $10 \mathrm{~kg} / \mathrm{d}$ by using a peristaltic pump (Type 115/G42 with L-channels; Ole Dich Instrumentmakers, Hvidovre, Denmark). Samples were collected from cows on d 21 of each period. Cows were fed the same diet, with both treatments (Table 1) formulated using the Nordic feed evaluation system (Volden, 2011). Diets were offered ad libitum (5\% orts as a minimum) and fed in 3 equally sized portions at 0800,1600 , and 2400 h. Cows were milked at 0600, 1400, and $2200 \mathrm{~h}$.

\section{Experimental Samplings}

Continuous infusion of $p$-aminohippuric acid $(\mathbf{p A H}$; $29.5 \pm 3.39 \mathrm{mmol} / \mathrm{h}$ ) into the mesenteric vein was initiated at least 60 min before the first blood sampling, using silicone tubing (No. 39339, $1 \mathrm{~mm}$ i.d., $3 \mathrm{~mm}$ o.d.; Ole Dich Instrumentmakers, Hvidovre, Denmark) connected by an adaptor to the mesenteric vein Tygon catheter (S-54-HL, $1.02 \mathrm{~mm}$ i.d. $\times 1.78 \mathrm{~mm}$ o.d.; ColeParmer, Vernon Hills, IL) and a peristaltic pump (Type 110-B; Ole Dich Instrumentmakers). The infusate was a $175 \mathrm{~m} M$ solution of pAH (99\% 4-aminohippuric acid; 
Table 1. Ingredient and nutrient composition of the basal diet $(\mathrm{g} / \mathrm{kg}$ of DM unless otherwise noted)

\begin{tabular}{|c|c|}
\hline Item & Experimental diet \\
\hline \multicolumn{2}{|l|}{ Ingredient } \\
\hline Corn silage $^{1}$ & 298 \\
\hline Grass clover silage $^{2}$ & 250 \\
\hline Barley, rolled & 298 \\
\hline Soybean meal, $54 \% \mathrm{CP}$ & 50 \\
\hline Soybean hulls & 57 \\
\hline Molasses, sugar cane & 13 \\
\hline Mineral and vitamin premix ${ }^{3}$ & 7 \\
\hline Vegetable fat ${ }^{4}$ & 10 \\
\hline $\mathrm{NaHCO}_{3}$ & 5 \\
\hline $\mathrm{CaCO}_{3}$ & 10 \\
\hline $\mathrm{Na}_{2} \mathrm{SO}_{4}$ & 2 \\
\hline Chromium(III) oxide & 1 \\
\hline \multicolumn{2}{|l|}{ Nutrient } \\
\hline $\mathrm{DM}, \mathrm{g} / \mathrm{kg}$ & $425 \pm 11$ \\
\hline Ash & 64 \\
\hline $\mathrm{CP}$ & 139 \\
\hline Crude fat & 37 \\
\hline NDF & 373 \\
\hline Starch & 273 \\
\hline $\mathrm{RDP}^{5}$ & 96 \\
\hline $\mathrm{MP}^{5}$ & 83 \\
\hline $\mathrm{NE}_{\mathrm{L}},{ }^{5} \mathrm{MJ} / \mathrm{kg}$ of $\mathrm{DM}$ & 6.90 \\
\hline
\end{tabular}

${ }^{1}$ Chemical composition of corn silage: DM, 33.6\%; ash, $2.9 \%$ of DM; $\mathrm{CP}, 8.6 \%$ of DM; crude fat, $2.2 \%$ of DM; NDF, $32.7 \%$ of DM; starch, $31.7 \%$ of DM.

${ }^{2}$ Chemical composition of grass clover silage: DM, $41.7 \%$; ash, $8.6 \%$ of $\mathrm{DM}$; CP, $16.6 \%$ of DM; crude fat, $4.4 \%$ of DM; NDF, $32.6 \%$ of DM; starch, $1.0 \%$ of DM.

${ }^{3}$ Premix contained the following (per $\mathrm{kg}$ ): $160 \mathrm{~g}$ of Ca, $45 \mathrm{~g}$ of P, $60 \mathrm{~g}$ of $\mathrm{Mg}, 80 \mathrm{~g}$ of Na, $5 \mathrm{~g}$ of S, $546 \mathrm{kIU}$ of vitamin A, $173 \mathrm{kIU}$ of vitamin $\mathrm{D}, 3,640 \mathrm{mg}$ of $\alpha$-tocopherol, 3,640 $\mathrm{mg}$ of $\mathrm{Mn}, 820 \mathrm{mg}$ of $\mathrm{Cu}, 23 \mathrm{mg}$ of Co, $4,090 \mathrm{mg}$ of Zn, $204 \mathrm{mg}$ of I, and $45 \mathrm{mg}$ of Se (VM 2; Vitfoss, Gråsten, Denmark).

${ }^{4}$ Palm fatty acid distillate (Scanfedt A/S, Frederica, Denmark).

${ }^{5}$ Calculated from ingredient analysis using the Nordic Feed Evaluation System (Volden, 2011).

Acros, Geel, Belgium) adjusted to $\mathrm{pH}$ 7.4, filtered (Filter Top PES membrane $0.22 \mu \mathrm{m}$; Techno Plastic Products AG, Trasadingen, Switzerland), and autoclaved.

Eight sets of blood samples were obtained at $0.5 \mathrm{~h}$ before and at $0.5,1.5,2.5,3.5,4.5,5.5$, and $6.5 \mathrm{~h}$ after the $0800 \mathrm{~h}$ feeding. Before blood sampling, catheters were primed by drawing a minimum of 2 times the catheter volume into a blank syringe, and the blood was discarded. Hourly blood samples were collected for blood gas and oximetry measurements using heparinized 2-mL gas syringes (PICO50; Radiometer A/S, Copenhagen, Denmark). Samples were immediately placed on crushed ice. Arterial, portal, hepatic, and ruminal blood samples were drawn simultaneously using disposable syringes, and the blood was immediately transferred to heparin vacuettes (No. 455051; Greiner BioOne GmbH, Kremsmuenster, Austria). For all samples, the vacuettes were placed on ice immediately after sampling, and plasma was harvested by centrifugation at $3,000 \times g$ for $20 \mathrm{~min}$ at $4^{\circ} \mathrm{C}$. Plasma was stored at $-20^{\circ} \mathrm{C}$ until analysis.

Ruminal fluid from the ventral ruminal sac was sampled hourly using an extended suction strainer (\#RT; Bar Diamond, Parma, ID). Ruminal fluid was stabilized by combining $8 \mathrm{~mL}$ of ruminal fluid with 2 $\mathrm{mL}$ of $25 \%$ metaphosphoric acid and stored at $-20^{\circ} \mathrm{C}$ until analysis.

Feces were sampled in the morning and afternoon of the day before and on the sampling day. Fecal fluid was extracted immediately by mixing $20 \mathrm{~g}$ of feces with $20 \mathrm{~g}$ of water, followed by centrifugation at $3,000 \times \mathrm{g}$ for $20 \mathrm{~min}$ at $4^{\circ} \mathrm{C}$. The supernatant was stabilized by combining $8 \mathrm{~mL}$ with $2 \mathrm{~mL}$ of $25 \%$ metaphosphoric acid and stored at $-20^{\circ} \mathrm{C}$ until analysis. Fecal samples were subsequently pooled within cow and sampling day and stored at $-20^{\circ} \mathrm{C}$ until analysis. Urine was sampled hourly by stimulating the cow to urinate by hand sweeping the supramammary region and stored at $-20^{\circ} \mathrm{C}$ until analysis.

Feed intake and milk yield were recorded daily. The diet was sampled daily for DM determination, and dried feed samples were pooled within each period for later chemical analysis. Milk yield was recorded using continuous-flow sampling (TruTest HI; Tru-Test Scandinavia, Præstø, Denmark), and milk was sampled on the sampling days at each milking from the continuousflow sample. Cows were weighed after the last sampling of each sampling day.

\section{Analytical Procedures}

Frozen pooled samples of silages were analyzed using near-infrared spectroscopy at a commercial feed testing laboratory (Eurofins Steins A/S, Holstebro, Denmark). The basal diet and feces were analyzed for DM content, ash, CP, crude fat, NDF, and starch, as described previously (Kristensen et al., 2007). Chromic oxide was analyzed colorimetrically according to the method of Schürch et al. (1950). Ruminal, fecal, and urinary $\mathrm{pH}$ were measured using a combination electrode (PHC2002-8; Hach Lange APS, Brønshøj, Denmark) and $\mathrm{pH}$ meter calibrated at $\mathrm{pH} 4.005$ and 7.000 (PHM 240; Hach Lange APS). Blood $\mathrm{pH}$, blood gasses, and oximetry variables were measured using an ABL700 Blood Gas Analyzer (Radiometer A/S, Copenhagen, Denmark). Hematocrit was determined immediately in arterial samples by centrifugation in capillary tubes at $13,000 \times g$ for 6 min at ambient temperature. Plasma samples were analyzed for glucose and L-lactate using D-glucose oxidase and L-lactate oxidase, respectively (YSI 7100; YSI Inc., Yellow Springs, OH). For pAH determination, plasma and urine were deacetylated 
before analysis by the method described by Harvey and Brothers (1962) using a continuous-flow analyzer (Autoanalyzer 3, method US-216-72 Rev. 1; Seal Analytical Ltd., Burgess Hill, UK). Before deacetylation of pAH, plasma was deproteinized by combining with an equal volume of $20 \%$ TCA (wt/vol), and the supernatant was incubated at $100^{\circ} \mathrm{C}$ for $1 \mathrm{~h}$. Plasma and urine concentrations of urea- $\mathrm{N}$ were determined by the method described by Marsh et al. (1965), using a continuous-flow analyzer (Autoanalyzer 3, method G-373-07 Rev. 1). Urea-N was determined in samples that had not been heat treated or deproteinized. Ammonia concentrations in feces, ruminal fluid, and plasma were determined using an enzymatic assay (AM 1015; Randox Laboratories Ltd., Crumlin, UK) adapted for use on a Cobas Mira autoanalyzer (Triolab A/S, Brøndby, Denmark). Total $\mathrm{N}$ in urine was determined using the Kjeldahl procedure (AOAC, 1990). Ammonia in ruminal fluid was analyzed after a 1:20 dilution with $100 \mathrm{~m} M$ phosphate buffer. Ruminal fluid and fecal fluid were analyzed for VFA by gas chromatography (Kristensen et al., 1996). Milk samples were analyzed for fat, protein, and lactose (monohydrate) by infrared spectrometry, using a MilkoScan 4000 instrument (Eurofins Steins A/S, Holstebro, Denmark). Milk urea-N content was determined by the monoxime diacetyl method (see above) after deproteinization by combining raw milk samples with an equal volume of $24 \%$ TCA.

\section{Calculations and Statistical Procedures}

Energy-corrected milk yield was calculated by taking lactose content into account (Sjaunja et al., 1991), using milk compositions corrected for differences in milk volume among the morning, afternoon, and evening milkings. Total tract digestibilities of OM (including abomasal infusion of OLIGO), $\mathrm{N}$, and starch were calculated using $\mathrm{Cr}_{2} \mathrm{O}_{3}$ as a digestibility marker and the average nutrient intake of the $6 \mathrm{~d}$ preceding the sampling days.

The $\mathrm{NH}_{3}$ concentration in whole blood was set equal to the plasma concentration, whereas the whole-blood concentration of urea- $\mathrm{N}$ was obtained by correcting for the urea dilution space in erythrocytes ( $80 \%$ of erythrocyte volume; Røjen et al., 2011). The portal blood plasma flow was calculated as infusion rate of $\mathrm{pAH} /$ (portal plasma pAH concentration - arterial plasma pAH concentration). The hepatic blood plasma flow was calculated as infusion rate of $\mathrm{pAH} /$ (hepatic plasma pAH concentration - arterial plasma pAH concentration). Whole-blood flows were calculated as plasma flow/[1 - (hematocrit/100)]. The study herein is dealing with splanchnic metabolism (i.e., the absorptive and liver tissues that assimilate and process incoming nutrients from the diet). Hence, the net flux calculations are based on blood or blood plasma flows and venous - arterial concentration differences according to the convention for studies on splanchnic nutrient fluxes (Reynolds, 2002). The net portal flux was calculated as portal blood or plasma flow $\times$ (portal concentration - arterial concentration) by using whole-blood or plasma values as indicated. The net hepatic flux was calculated as hepatic blood or plasma flow $\times$ hepatic concentration $-[$ (portal blood or plasma flow $\times$ arterial concentration)], where the hepatic arterial blood or plasma flow was calculated as hepatic blood or plasma flow - portal blood or plasma flow. The net splanchnic flux was calculated as hepatic blood or plasma flow $\times$ (hepatic concentration - arterial concentration). Positive net fluxes indicate production or release, whereas negative net fluxes indicate uptake or transfer of the substance. Portal and ruminal vein extractions for urea$\mathrm{N}$ were calculated as $100 \times$ (arterial urea- $\mathrm{N}$ concentration - venous urea- $\mathrm{N}$ concentration)/arterial urea- $\mathrm{N}$ concentration. Renal metabolite kinetics was calculated according to the method of Røjen et al. (2011).

The MIXED procedure in SAS [version 9.1 (TS1M3); SAS Institute Inc., Cary, NC] was used for statistical analyses. Variables with only one observation within cow and sampling day were subjected to ANOVA according to the crossover design. Treatment sequence, period, and dietary treatment were described as fixed effects, and cow within sequence was described as a random effect. Dry matter intake and milk yield were analyzed using the average from the last $7 \mathrm{~d}$ of the periods. Data on metabolite concentrations and fluxes were analyzed according to the crossover design. The model had treatment sequence, period, dietary treatment, sampling time, and the interaction of dietary treatment $\times$ sampling time as fixed effects. Cow within sequence was included as a random effect. Sampling times within cow $\times$ period were considered repeated measures. Covariance structures were modeled using autoregressive order 1 , based on model convergence and fit statistics. Some values were missing: 2 cows had no functional ruminal vein catheter, and 1 cow had a misplaced portal catheter. In period 2, 1 cow had missing hepatic blood samples. When calculating diuresis, urinary urea- $\mathrm{N}$ excretion, and renal clearance of blood urea-N, the first observation within sampling times was deleted from the data set because we could not be certain that urine concentration of $\mathrm{pAH}$ had reached steady-state conditions. Data are presented as least squares means \pm residual errors of the means. Significance was declared at $P \leq 0.05$, and tendencies were considered at $0.05<P \leq 0.10$. 


\section{RESULTS}

Dry matter intake decreased $(P<0.01)$ by $0.74 \pm$ $0.20 \mathrm{~kg} / \mathrm{d}$ in the OLIGO treatment compared with the CTRL treatment, equivalent to half the infused amount of oligofructose (Table 2). Correspondingly, N intake also decreased $(P<0.01)$ with the OLIGO treatment. Milk yield, ECM, fat yield, protein yield, and lactose yield did not differ $(P=0.30$ to $P=0.87)$ between treatments. The urea-N concentration in milk decreased $(P$ $=0.04)$ with the OLIGO treatment, whereas milk fat, protein, and lactose concentrations were not affected $(P=0.26$ to $P=0.68)$ by treatment. The $\mathrm{N}$ content of milk was not different $(P=0.87)$ between treatments. The calculated apparent $\mathrm{N}$ utilization for milk production tended to be greater $(P=0.08)$ for the OLIGO treatment compared with the CTRL treatment. None of the ruminal variables was affected $(P=0.13$ to $P=$ 0.96 ; Table 3) by treatment.

\section{Fecal Variables}

Fecal $\mathrm{pH}$ and fecal $\mathrm{NH}_{3}$ concentration decreased $(P$ $<0.01$ ), whereas fecal DM content, amount of DM excreted, and L-lactate concentration increased $(P<$ 0.01 to $P=0.05$; Table 4) for the OLIGO treatment compared with the CTRL treatment. Fecal N excretion tended to increase $(P=0.06)$ in the OLIGO treatment compared with the CTRL treatment. The total concentration of VFA in fecal fluid was not affected $(P$
$=0.11$ ) by treatment; however, a numeric increase was observed for the OLIGO treatment. The molar proportions of acetate, propionate, isobutyrate, isovalerate, and valerate decreased $(P<0.01)$ in fecal fluid with the OLIGO treatment, whereas the molar proportion of butyrate increased $(P<0.01)$ in the OLIGO treatment compared with the CTRL treatment. The molar proportion of fecal caproate was not affected $(P=0.30)$ by treatments. The apparent total tract digestibility of $\mathrm{OM}, \mathrm{N}$, and starch decreased $(P<0.01)$ in the OLIGO treatment compared with the CTRL treatment. In the case of OM digestibility, the oligofructose infused was included in the calculations.

\section{Arterial Variables}

Arterial $\mathrm{pH}$, hematocrit, and arterial blood concentrations of $\mathrm{NH}_{3}$, and $\mathrm{O}_{2}$, and arterial plasma concentrations of pAH and L-lactate were not affected $(P=$ 0.14 to $P=0.79$ ) by treatment (Table 5 ). The arterial blood concentration of urea-N, and the arterial plasma concentration of glucose decreased $(P=0.03$ and $P$ $<0.01)$ in the OLIGO treatment compared with the CTRL treatment.

\section{Portal Venous - Arterial and Ruminal Venous - Arterial Concentration Differences}

The portal venous - arterial (PA) concentration differences for urea- $\mathrm{N}$ and $\mathrm{NH}_{3}$ were smaller $(P<0.01)$ in

Table 2. Dry matter intake, $\mathrm{N}$ intake, milk yield, milk composition, and apparent $\mathrm{N}$ utilization for milk production

\begin{tabular}{|c|c|c|c|c|}
\hline \multirow[b]{2}{*}{ Item } & \multicolumn{2}{|c|}{ Treatment $^{1}$} & \multirow[b]{2}{*}{$\mathrm{SEM}^{2}$} & \multirow[b]{2}{*}{$P$-value ${ }^{3}$} \\
\hline & CTRL & OLIGO & & \\
\hline Voluntary DMI, kg/d & 19.7 & 19.0 & 0.64 & $<0.01$ \\
\hline $\mathrm{N}$ intake, $\mathrm{g} / \mathrm{d}$ & 439 & 423 & 14.2 & $<0.01$ \\
\hline \multicolumn{5}{|l|}{ Milk yield } \\
\hline Milk yield, kg/d & 34.4 & 34.2 & 1.0 & 0.51 \\
\hline ECM yield, $\mathrm{kg} / \mathrm{d}$ & 31.5 & 31.9 & 1.1 & 0.42 \\
\hline Fat yield, $\mathrm{g} / \mathrm{d}$ & 1,250 & 1,290 & 52 & 0.30 \\
\hline Protein yield, g/d & 971 & 973 & 36 & 0.87 \\
\hline Lactose yield, $\mathrm{g} / \mathrm{d}$ & 1,708 & 1,690 & 57 & 0.51 \\
\hline \multicolumn{5}{|l|}{ Milk composition } \\
\hline Fat, $\mathrm{g} / \mathrm{kg}$ & 3.63 & 3.78 & 0.12 & 0.26 \\
\hline Protein, $\mathrm{g} / \mathrm{kg}$ & 2.82 & 2.85 & 0.06 & 0.35 \\
\hline Lactose, $\mathrm{g} / \mathrm{kg}$ & 4.96 & 4.94 & 0.04 & 0.68 \\
\hline Milk urea-N, ${ }^{4} \mathrm{mmol} / \mathrm{L}$ & 4.33 & 3.38 & 0.30 & 0.04 \\
\hline Milk N, g/d & 152 & 153 & 5.6 & 0.87 \\
\hline Apparent $\mathrm{N}$ utilization for milk protein, $\%$ & 34.7 & 36.3 & 0.95 & 0.08 \\
\hline
\end{tabular}


Table 3. Ruminal variables

\begin{tabular}{|c|c|c|c|c|c|}
\hline \multirow[b]{2}{*}{ Item } & \multicolumn{2}{|c|}{ Treatment $^{1}$} & \multirow[b]{2}{*}{$\mathrm{SEM}^{2}$} & \multicolumn{2}{|c|}{$P$-value ${ }^{3}$} \\
\hline & CTRL & OLIGO & & Trt & Time \\
\hline Ruminal pH & 6.46 & 6.48 & 0.075 & 0.61 & $<0.01$ \\
\hline $\mathrm{NH}_{3}, \mathrm{mmol} / \mathrm{L}$ & 3.17 & 2.68 & 0.256 & 0.19 & $<0.01$ \\
\hline Glucose, mmol/L & 0.14 & 0.12 & 0.014 & 0.14 & $<0.01$ \\
\hline L-Lactate, mmol/L & 0.98 & 0.89 & 0.265 & 0.80 & $<0.01$ \\
\hline Total VFA, mmol/L & 105.9 & 104.9 & 2.895 & 0.63 & $<0.01$ \\
\hline Acetate, mol/100 mol & 56.5 & 57.2 & 1.004 & 0.39 & $<0.01$ \\
\hline Propionate, mol/100 mol & 26.1 & 24.9 & 1.37 & 0.14 & $<0.01$ \\
\hline Isobutyrate, $\mathrm{mol} / 100 \mathrm{~mol}$ & 0.820 & 0.820 & 0.032 & 0.96 & $<0.01$ \\
\hline Butyrate, mol/100 mol & 12.53 & 13.02 & 0.643 & 0.39 & $<0.01$ \\
\hline Isovalerate, $\mathrm{mol} / 100 \mathrm{~mol}$ & 1.47 & 1.57 & 0.077 & 0.13 & $<0.01$ \\
\hline Valerate, mol/100 mol & 1.94 & 1.88 & 0.174 & 0.48 & $<0.01$ \\
\hline Caproate, mol/100 mol & 0.61 & 0.63 & 0.078 & 0.73 & $<0.01$ \\
\hline
\end{tabular}

${ }^{1}$ Treatments were continuous abomasal infusion of water (CTRL), and 1,500 g/d of oligofructose (OLIGO; Orafti P95, Alisano, Birkerød, Denmark).

${ }^{2} \mathrm{n}=9$.

${ }^{3} P$-values for treatment (Trt) and time within sampling day (Time). Significance was declared when $P \leq 0.05$ and a tendency when $P \leq 0.10$.

the OLIGO treatment compared with the CTRL treatment (Table 6), whereas the ruminal venous - arterial (RA) concentration difference for urea- $\mathrm{N}$ and $\mathrm{NH}_{3}$ did not differ $(P=0.26$ and $P=0.93)$ between treatments. The PDV extraction of urea-N from arterial blood increased $(P=0.01)$ in the OLIGO treatment compared with the CTRL treatment, whereas the ruminal extraction of urea-N from arterial blood was not affected $(P$ $=0.44$ ) by treatment, although it was greater than the PDV urea-N extraction of arterial urea-N (16.9 and
18.7\% compared with 4.7 and $5.4 \%$ for CTRL and OLI$\mathrm{GO}$, respectively). The PA differences for urea-N were not affected $(P=0.18)$ by time, whereas the RA differences for urea-N and the PA and RA differences for $\mathrm{NH}_{3}$ increased $(P=0.01$ and $P<0.01)$ postprandially, reaching a zenith at $1.5 \mathrm{~h}$ after feeding and then gradually decreasing toward prefeeding levels. Both PDV and ruminal extractions of arterial urea- $\mathrm{N}$ were affected $(P$ $<0.01$ ) by time. Ruminal extraction of arterial urea-N decreased after feeding, with the nadir observed at 1.5

Table 4. Fecal variables and apparent digestibility of OM, N, and starch

\begin{tabular}{|c|c|c|c|c|}
\hline \multirow[b]{2}{*}{ Item } & \multicolumn{2}{|c|}{ Treatment $^{1}$} & \multirow[b]{2}{*}{$\mathrm{SEM}^{2}$} & \multirow[b]{2}{*}{$P$-value ${ }^{3}$} \\
\hline & CTRL & OLIGO & & \\
\hline Fecal pH & 6.81 & 6.10 & 0.08 & $<0.01$ \\
\hline Fecal DM, \% & 13.3 & 14.5 & 0.1 & 0.03 \\
\hline Fecal DM, kg/d & 5.2 & 6.1 & 0.2 & $<0.01$ \\
\hline Fecal N, g/d & 185 & 193 & 5 & 0.06 \\
\hline $\mathrm{L}$-Lactate, $\mathrm{mmol} / \mathrm{L}$ & 0.273 & 7.919 & 2.454 & 0.05 \\
\hline $\mathrm{NH}_{3}, \mathrm{mmol} / \mathrm{L}$ & 2.511 & 0.087 & 0.151 & $<0.01$ \\
\hline Total VFA, mmol/L & 26.9 & 32.3 & 2.3 & 0.11 \\
\hline Acetate, $\mathrm{mol} / 100 \mathrm{~mol}$ & 77.2 & 65.2 & 2.4 & $<0.01$ \\
\hline Propionate, $\mathrm{mol} / 100 \mathrm{~mol}$ & 14.1 & 3.2 & 0.5 & $<0.01$ \\
\hline Isobutyrate, $\mathrm{mol} / 100 \mathrm{~mol}$ & 0.73 & 0.11 & 0.05 & $<0.01$ \\
\hline Butyrate, mol/100 mol & 6.8 & 31.2 & 2.4 & $<0.01$ \\
\hline Isovalerate, $\mathrm{mol} / 100 \mathrm{~mol}$ & 0.37 & 0.12 & 0.05 & $<0.01$ \\
\hline Valerate, $\mathrm{mol} / 100 \mathrm{~mol}$ & 0.76 & 0.07 & 0.06 & $<0.01$ \\
\hline Caproate, mol/100 mol & 0.02 & 0.02 & 0.003 & 0.30 \\
\hline Apparent OM digestibility, ${ }^{4} \%$ & 74.7 & 70.9 & 0.6 & $<0.01$ \\
\hline Apparent $\mathrm{N}$ digestibility, $\%$ & 57.9 & 54.2 & 1.1 & $<0.01$ \\
\hline Apparent starch digestibility, $\%$ & 98.5 & 95.5 & 0.4 & $<0.01$ \\
\hline
\end{tabular}

${ }^{1}$ Treatments were continuous abomasal infusion of water (CTRL), and 1,500 g/d of oligofructose (OLIGO; Orafti P95, Alisano, Birkerød, Denmark).

${ }^{2} \mathrm{n}=9$.

${ }^{3} P$-values for treatment (Trt). Significance was declared when $P \leq 0.05$ and a tendency when $P \leq 0.10$.

${ }^{4}$ Digestibility calculation includes infused oligofructose. 
Table 5. Arterial variables

\begin{tabular}{|c|c|c|c|c|c|}
\hline \multirow[b]{2}{*}{ Item } & \multicolumn{2}{|c|}{ Treatment $^{1}$} & \multirow[b]{2}{*}{$\mathrm{SEM}^{2}$} & \multicolumn{2}{|c|}{$P$-value ${ }^{3}$} \\
\hline & CTRL & OLIGO & & Trt & Time \\
\hline \multicolumn{6}{|l|}{ Arterial whole blood } \\
\hline $\mathrm{pH}$ & 7.44 & 7.43 & 0.01 & 0.21 & 0.39 \\
\hline Hematocrit, \% & 24.5 & 24.6 & 0.7 & 0.54 & 0.58 \\
\hline $\mathrm{NH}_{3}, \mathrm{mmol} / \mathrm{L}$ & 0.116 & 0.115 & 0.004 & 0.79 & 0.25 \\
\hline Urea-N, mmol/L & 4.79 & 3.77 & 0.30 & 0.03 & $<0.01$ \\
\hline $\mathrm{O}_{2}, \mathrm{mmol} / \mathrm{L}$ & 5.07 & 5.11 & 0.16 & 0.39 & 0.82 \\
\hline $\mathrm{CO}_{2}, \mathrm{mmol} / \mathrm{L}$ & 27.2 & 26.5 & 0.5 & 0.10 & $<0.01$ \\
\hline \multicolumn{6}{|l|}{ Arterial blood plasma } \\
\hline p-Aminohippuric acid, mmol/L & 0.079 & 0.087 & 0.006 & 0.36 & $<0.01$ \\
\hline Glucose, $\mathrm{mmol} / \mathrm{L}$ & 3.72 & 3.51 & 0.06 & $<0.01$ & $<0.01$ \\
\hline L-Lactate, $\mathrm{mmol} / \mathrm{L}$ & 0.499 & 0.436 & 0.030 & 0.14 & $<0.01$ \\
\hline
\end{tabular}

${ }^{1}$ Treatments were continuous abomasal infusion of water (CTRL), and 1,500 g/d of oligofructose (OLIGO; Orafti P95, Alisano, Birkerød, Denmark).

${ }^{2} \mathrm{n}=9$.

${ }^{3} P$-values for treatment (Trt) and time within sampling day (Time). Significance was declared when $P \leq 0.05$ and a tendency when $P \leq 0.10$.

to $3.5 \mathrm{~h}$ after feeding; hereafter, extraction increased toward the prefeeding level. Portal-drained visceral extraction of arterial urea- $\mathrm{N}$ appeared to be affected in a less apparent way by time relative to feeding.

\section{Net Splanchnic Fluxes}

The net uptake of urea- $\mathrm{N}$ from the blood to PDV tissues (negative net portal flux) and the net portal release of $\mathrm{NH}_{3}$ from the PDV to the blood (positive net portal flux $)$ decreased $(P<0.01$; Table 7$)$ in the OLIGO treatment compared with the CTRL treatment. The net portal flux of glucose was numerically greater with the OLIGO treatment $(P=0.14)$, approximately equivalent to the amounts of free glucose, fructose, and sucrose in the infused oligofructose (based on manufacturer information), and going from a net portal uptake to a net portal release with the CTRL and OLIGO treatments, respectively. The net portal release of Llactate was not affected $(P=0.24)$ by treatment. The net portal release of $\mathrm{NH}_{3}$ increased $(P<0.01)$ after feeding, before gradually returning toward prefeeding levels. The net portal flux of glucose tended to increase $(P=0.06)$ slightly during sampling times.

The net hepatic urea- $\mathrm{N}$ release and the net hepatic $\mathrm{NH}_{3}$ uptake were increased $(P<0.01)$ in the CTRL treatment compared with the OLIGO treatment. The net hepatic release of glucose was decreased $(P=0.03)$ and the net hepatic uptake of lactate was increased $(P<0.01)$ in the OLIGO treatment compared with the CTRL treatment. The net hepatic urea-N release increased $(P<0.01)$ after feeding, reaching the zenith at 0.5 to $2.5 \mathrm{~h}$ after feeding, and then decreasing toward prefeeding levels. The same time pattern was observed with net hepatic uptake of $\mathrm{NH}_{3}(P<0.01)$. Net hepatic uptake of L-lactate tended to be affected $(P=0.10)$ by

Table 6. Venous - arterial concentration differences for urea-N and $\mathrm{NH}_{3}$ across the portal-drained viscera (PDV) and ruminal wall, and PDV and ruminal extractions of arterial urea-N

\begin{tabular}{|c|c|c|c|c|c|}
\hline \multirow[b]{2}{*}{ Item } & \multicolumn{2}{|c|}{ Treatment $^{1}$} & \multirow[b]{2}{*}{$\mathrm{SEM}^{2}$} & \multicolumn{2}{|c|}{$P$-value ${ }^{3}$} \\
\hline & CTRL & OLIGO & & Trt & Time \\
\hline Portal - arterial urea-N, mmol/L & -0.225 & -0.195 & 0.015 & $<0.01$ & 0.18 \\
\hline Ruminal - arterial urea-N, mmol/L & -0.765 & -0.712 & 0.086 & 0.26 & $<0.01$ \\
\hline Portal - arterial $\mathrm{NH}_{3}, \mathrm{mmol} / \mathrm{L}$ & 0.241 & 0.193 & 0.015 & $<0.01$ & $<0.01$ \\
\hline Ruminal - arterial $\mathrm{NH}_{3}, \mathrm{mmol} / \mathrm{L}$ & 0.618 & 0.614 & 0.065 & 0.93 & $<0.01$ \\
\hline PDV extraction of arterial urea-N, \% & 4.7 & 5.4 & 0.4 & 0.01 & 0.01 \\
\hline Ruminal extraction of arterial urea-N, \% & 16.9 & 18.7 & 2.6 & 0.44 & $<0.01$ \\
\hline
\end{tabular}

${ }^{1}$ Treatments were continuous abomasal infusion of water (CTRL), and 1,500 g/d of oligofructose (OLIGO; Orafti P95, Alisano, Birkerød, Denmark).

${ }^{2} \mathrm{n}=9$, except for ruminal - arterial urea- $\mathrm{N}$ and $\mathrm{NH}_{3}$ concentration differences, and ruminal extraction of arterial urea-N, where $\mathrm{n}=7$.

${ }^{3} P$-values for treatment (Trt) and time within sampling day (Time). Significance was declared when $P \leq 0.05$ and a tendency when $P \leq 0.10$. 
Table 7. Blood plasma flows, net portal, net hepatic, and net splanchnic fluxes

\begin{tabular}{|c|c|c|c|c|c|}
\hline \multirow[b]{2}{*}{ Item } & \multicolumn{2}{|c|}{ Treatment $^{1}$} & \multirow[b]{2}{*}{$\mathrm{SEM}^{2}$} & \multicolumn{2}{|c|}{$P$-value ${ }^{3}$} \\
\hline & CTRL & OLIGO & & Trt & Time \\
\hline \multicolumn{6}{|c|}{ Blood plasma flows, $\mathrm{L} / \mathrm{h}$} \\
\hline Portal vein & 1,510 & 1,527 & 95 & 0.68 & $<0.01$ \\
\hline Hepatic vein & 1,512 & 1,576 & 71 & 0.04 & $<0.04$ \\
\hline Hepatic artery & 31 & 76 & 81 & 0.34 & 0.07 \\
\hline \multicolumn{6}{|c|}{ Net portal whole blood flux, $\mathrm{mmol} / \mathrm{h}$} \\
\hline Urea-N & -235 & -196 & 19 & $<0.01$ & 0.37 \\
\hline $\mathrm{NH}_{3}$ & 480 & 383 & 29 & $<0.01$ & $<0.01$ \\
\hline $\mathrm{O}_{2}$ & $-2,619$ & $-2,632$ & 181 & 0.87 & 0.14 \\
\hline $\mathrm{CO}_{2}$ & 2,881 & 3,052 & 198 & 0.35 & 0.10 \\
\hline \multicolumn{6}{|c|}{ Net portal plasma flux, $\mathrm{mmol} / \mathrm{h}$} \\
\hline Glucose & -6 & 18 & 12 & 0.14 & 0.06 \\
\hline L-Lactate & 213 & 224 & 15 & 0.24 & 0.75 \\
\hline \multicolumn{6}{|c|}{ Net hepatic whole blood flux, $\mathrm{mmol} / \mathrm{h}$} \\
\hline Urea-N & 318 & 235 & 17 & $<0.01$ & $<0.01$ \\
\hline $\mathrm{NH}_{3}$ & -485 & -371 & 32 & $<0.01$ & $<0.01$ \\
\hline $\mathrm{O}_{2}$ & $-2,381$ & $-2,401$ & 134 & 0.88 & 0.03 \\
\hline $\mathrm{CO}_{2}$ & 1,239 & 1,279 & 198 & 0.78 & 0.17 \\
\hline \multicolumn{6}{|c|}{ Net hepatic plasma flux, $\mathrm{mmol} / \mathrm{h}$} \\
\hline Glucose & 737 & 680 & 29 & 0.03 & 0.30 \\
\hline L-Lactate & -166 & -226 & 11 & $<0.01$ & 0.10 \\
\hline \multicolumn{6}{|c|}{ Net splanchnic whole blood } \\
\hline \multicolumn{6}{|c|}{ flux, $\mathrm{mmol} / \mathrm{h}$} \\
\hline Urea-N & 77 & 39 & 7 & $<0.01$ & $<0.01$ \\
\hline $\mathrm{NH}_{3}$ & 2.2 & 10.5 & 2.9 & 0.04 & 0.78 \\
\hline $\mathrm{O}_{2}$ & $-4,939$ & $-4,976$ & 197 & 0.76 & $<0.01$ \\
\hline $\mathrm{CO}_{2} *$ & 4,265 & 4,351 & 187 & 0.63 & 0.14 \\
\hline \multicolumn{6}{|c|}{ Net splanchnic plasma flux, mmol/h } \\
\hline Glucose & 734 & 700 & 29 & 0.16 & 0.01 \\
\hline L-Lactate & 57 & 7 & 20 & $<0.01$ & $<0.01$ \\
\hline
\end{tabular}

${ }^{1}$ Treatments were continuous abomasal infusion of water (CTRL), and 1,500 g/d of oligofructose (OLIGO; Orafti P95, Alisano, Birkerød, Denmark).

${ }^{2} \mathrm{n}=9$.

${ }^{3} P$-values for treatment (Trt) and time within sampling day (Time). Significance was declared when $P \leq 0.05$ and a tendency when $P \leq 0.10$.

$* P=0.05$, treatment $\times$ time interaction.

time, but no obvious pattern was observed, and glucose was not affected $(P=0.17$ to $P=0.30)$ by time relative to feeding.

The net splanchnic release of urea- $\mathrm{N}$ reflects a larger hepatic production of urea- $\mathrm{N}$ than does uptake across the rumen and intestinal epithelia. The net splanchnic release of urea-N decreased $(P<0.01)$ in the OLIGO treatment compared with the CTRL treatment. The net splanchnic release of $\mathrm{NH}_{3}$ increased $(P=0.04)$ in the OLIGO treatment compared with the CTRL treatment, but the observed releases were small and averaged $6.8 \pm 1.77 \mathrm{mmol} / \mathrm{h}$. The net splanchnic release of L-lactate was decreased $(P<0.01)$ in the OLIGO treatment compared with the CTRL treatment, and the net splanchnic release of glucose was unaffected $(P=0.16)$ by treatment. The net splanchnic release of urea-N increased $(P<0.01)$ after feeding and then decreased toward prefeeding levels. The net splanchnic release of glucose appeared to increase $(P=0.01)$, whereas the net splanchnic release of L-lactate appeared to decrease $(P<0.01)$ in the first hours after feeding, followed by a decrease and an increase, respectively. However, some fluctuations during sampling time for the net splanchnic flux of glucose and L-lactate make the interpretations difficult.

\section{Renal Variables and Urea-N Kinetics}

Urinary $\mathrm{pH}$ tended to be lower $(P=0.10$; Table 8$)$ in the OLIGO treatment compared with the CTRL treatment. Diuresis, total urinary $\mathrm{N}$ excretion, urinary urea- $\mathrm{N}$ concentration, urinary urea- $\mathrm{N}$ excretion, and the renal clearance of blood urea- $\mathrm{N}$ were greater $(P<$ 0.01 to $P=0.05)$ in the CTRL treatment compared with the OLIGO treatment. The renal plasma flow was not affected $(P=0.64)$ by treatment. Diuresis, renal plasma flow, urea- $\mathrm{N}$ excretion, and urea- $\mathrm{N}$ clearance increased $(P<0.01$ to $P=0.02)$ after feeding and then gradually decreased toward the prefeeding level. Urinary urea-N concentration increased $(P<0.01)$ after 
Table 8. Renal variables and urea-N kinetics

\begin{tabular}{|c|c|c|c|c|c|}
\hline \multirow[b]{2}{*}{ Item } & \multicolumn{2}{|c|}{ Treatment $^{1}$} & \multirow[b]{2}{*}{$\mathrm{SEM}^{2}$} & \multicolumn{2}{|c|}{$P$-value ${ }^{3}$} \\
\hline & CTRL & OLIGO & & Trt & Time \\
\hline Urinary pH & 8.05 & 8.01 & 0.02 & 0.10 & $<0.01$ \\
\hline Diuresis, L/h & 0.84 & 0.72 & 0.05 & 0.05 & 0.02 \\
\hline Renal plasma flow, $\mathrm{L} / \mathrm{h}$ & 369 & 362 & 21 & 0.64 & $<0.01$ \\
\hline Urinary N, g/d & 98 & 79 & 5 & $<0.01$ & - \\
\hline Urinary urea-N concentration, $\mathrm{mmol} / \mathrm{L}$ & 183.6 & 135.8 & 14.4 & 0.02 & $<0.01$ \\
\hline Urinary urea-N excretion, $\mathrm{mmol} / \mathrm{h}$ & 150.0 & 98.6 & 9.4 & $<0.01$ & $<0.01$ \\
\hline Renal clearance of blood urea-N, L/h & 31.4 & 26.3 & 2.5 & $<0.01$ & $<0.01$ \\
\hline
\end{tabular}

feeding and continued to increase slightly, with only a small decrease at the very end of the sampling period.

\section{DISCUSSION}

In ruminants, data are sparse on the effects of increased fermentation in the hindgut independent of ruminal acidosis. The hindgut is herein defined as the cecum, colon, and rectum. The abomasally infused oligofructose is a carbohydrate produced from partial enzymatic hydrolysis of inulin and is composed of fructose units linked by $\beta-(2 \rightarrow 1)$ linkages; it is readily fermented by microorganisms but not digested by mammalian endogenous enzymes (Roberfroid and Delzenne, 1998). In lactating dairy cows, fecal excretion of inulin compared with abomasal infusion of inulin indicated that $99 \%$ of the infused amount was digested (Gressley and Armentano, 2005). The lower degree of polymerization of oligofructose compared with inulin makes it reasonable to assume that oligofructose is entirely digested in the large intestine. The amount of oligofructose infused in this study was expected to more than double the amount of hindgut fermentation with reference to studies in duodenally and ileally cannulated lactating cows on a variety of diets, which reported an average of 1 $\mathrm{kg} / \mathrm{d}$ of $\mathrm{OM}$ to be digested in the hindgut (Gressley et al., 2011).

\section{Fecal Effects of Oligofructose Infusion}

The end products of hindgut fermentation are similar to those of ruminal fermentation and include, in addition to microbial matter, VFA (mainly acetate, propionate, and butyrate), lactate, $\mathrm{NH}_{3}$, and the gases $\mathrm{CO}_{2}, \mathrm{CH}_{4}$, and $\mathrm{H}_{2}$ (Wolin, 1981; Hume, 1997; Roberfroid and Delzenne, 1998). Studies applying lower abomasal infusion rates of carbohydrates compared with this study $(1.2 \mathrm{~kg} / \mathrm{d}$ of wheat starch, and $1 \mathrm{~kg} / \mathrm{d}$ of pectin or inulin) showed decreased fecal $\mathrm{pH}$ (6.64 to 6.26; Reynolds et al., 2001) or no effect on fecal pH and total VFA concentration (Gressley et al., 2011) with infusion and found no apparent signs of hindgut acidosis. Increasing the abomasal infusion of corn starch up to $4 \mathrm{~kg} / \mathrm{d}$ in lactating dairy cows and in horses fed $10 \mathrm{~g}$ of oligofructose $/ \mathrm{kg}$ of $\mathrm{BW}$ decreased the fecal $\mathrm{pH}$ from approximate 7 to $<5$ and included signs of decreased feed intake, laminitis, intestinal damage, and diarrhea (Milinovich et al., 2006; Bissell and Hall, 2010), which are typical field signs of increased hindgut fermentation in relation to subacute ruminal acidosis (Plaizier et al., 2008). In the current study, quantitative indicators of increased hindgut fermentation were decreased fecal $\mathrm{pH}$ and increased fecal lactate concentrations. In addition, total fecal VFA concentration was numerically higher with the OLIGO treatment and feces appeared watery, but the cows did not show overt signs of discomfort. The data from the present study suggest that continuous abomasal infusion of up to $1.5 \mathrm{~kg} / \mathrm{d}$ of oligofructose increased hindgut fermentation but did not induce acidotic conditions.

The fecal DM output was increased by $0.9 \mathrm{~kg} / \mathrm{d}$ with the OLIGO treatment. This is similar to the report in lactating cows by Gressley and Armentano (2005), who observed an increase in fecal DM output by 0.8 $\mathrm{kg} / \mathrm{d}$ with abomasal infusion of $1 \mathrm{~kg}$ of inulin. This could be an indication of increased fecal microbial DM excretion. However, using fecal purine output, Gressley and Armentano (2005) estimated that an average of only 4.3 and $24.4 \%$ of the increase in fecal DM output with inulin infusion for a low- and high-protein diet, respectively, was due to increased fecal microbial DM excretion. They concluded that because inulin was almost completely digested in the hindgut, the majority of increase in fecal DM with inulin infusion was due to inulin reducing the true digestibility of dietary components, including starch. In the current study, the 
OLIGO treatment reduced the apparent digestibility of starch from 98.5 to $95.5 \%$. Similarly, Gressley and Armentano $(2005,2007)$ found that abomasal infusions of pectin and inulin, respectively, reduced the apparent digestibility of starch. The authors suggested that the reduction in digestibility may have been due to the infused fiber interfering with small intestinal nutrient digestion or competing with other nutrients for large intestinal digestion. This may also apply to abomasal infusion of oligofructose, which delivers easily fermented soluble fiber to the small intestine.

The oligofructose infusion reduced the apparent digestibility of $\mathrm{N}$ from 57.9 to $54.2 \%$. Increased supplementation of fermentable carbohydrate to the hindgut has, on several occasions in both ruminants and monogastrics, been reported to decrease apparent $\mathrm{N}$ digestibility (Hesta et al., 2001; Gressley and Armentano, 2005; Hedemann and Knudsen, 2010). The main reason for this is speculated to be enhanced microbial protein synthesis in the hindgut resulting from the presence of the fermentable substrate (Hesta et al., 2001; Propst et al., 2003). Somewhat contrary to this hypothesis, Gressley and Armentano (2005) found that only 11 to $44 \%$ of the increase in fecal $\mathrm{N}$ with inulin infusion was due to increased fecal microbial $\mathrm{N}$ excretion, thus suggesting that the fermentable substrate reduced the true digestibility of dietary protein or increased the nonmicrobial endogenous protein losses. However, this might have been an artifact of the model used, in which infused inulin might have interfered with small intestinal nutrient digestion or competed with other nutrients for large intestinal digestion. In the present study, fecal $\mathrm{N}$ excretion tended to increase with the OLIGO treatment, in agreement with the general observation of increased fecal $\mathrm{N}$ excretion with increasing hindgut fermentation.

\section{Urea-N Transport}

In a situation with increased carbohydrate fermentation in the hindgut, $\mathrm{N}$ requirements are increased to ensure maximal bacterial growth. It has been proposed that the most readily available source of $\mathrm{N}$ for microbial protein synthesis is recycled urea-N (Thornton et al., 1970; Rémésy and Demigné, 1989; Younes et al., 1999). Data from studies, especially in rodents, have shown increased urea- $\mathrm{N}$ transfer across the cecum with an increasing supply of fermentable carbohydrate to the hindgut (Rémésy and Demigné, 1989; Levrat et al., 1993; Younes et al., 2001). Hence, the effects observed across animal species on fecal $\mathrm{N}$ excretion, urinary $\mathrm{N}$ excretion, and blood urea- $\mathrm{N}$ concentration have mainly been due to increased transfer of blood urea- $\mathrm{N}$ to the hindgut. However, this challenges the hypothesis that changes in net PDV uptake of urea- $\mathrm{N}$ are the actual causative link between changes in hindgut fermentation and $\mathrm{N}$ metabolism. Data compiled from several studies in dairy cattle have shown an incapability of increasing urea- $\mathrm{N}$ transfer to the gut tissues with decreasing $\mathrm{N}$ intake (Calsamiglia et al., 2010; Røjen et al., 2011; Røjen and Kristensen, 2012), and a large proportion of total PDV removal of blood urea-N appears to be accounted for by the forestomach (Theurer et al., 2002). In addition, in growing pigs, PDV uptake of urea-N was found to be very low (Kristensen et al., 2009). The present study supports the view that, in ruminants, a relationship exists between increased hindgut fermentation and a lowering of blood urea- $\mathrm{N}$ concentration; however, net PDV uptake of arterial blood urea-N was decreased with the OLIGO treatment, which suggests that the decrease in arterial blood urea- $\mathrm{N}$ concentration cannot be explained by increased urea- $\mathrm{N}$ transfer across the PDV tissues.

In the present study, ruminal $\mathrm{NH}_{3}$ concentrations averaged 3.17 and $2.68 \mathrm{mM}$ for the CTRL and OLIGO treatments, respectively, and were not affected by treatment. The lack of difference between treatments on ruminal extraction of arterial blood urea-N, ruminal $\mathrm{NH}_{3}$ concentration, and ruminal venous - arterial concentration differences for urea- $\mathrm{N}$ or $\mathrm{NH}_{3}$ strongly indicates that upregulation of urea- $\mathrm{N}$ transfer to the hindgut at the expense of urea-N uptake by the rumen was unlikely to have happened, and that rumen microbial protein synthesis was relatively unaffected by hindgut fermentation. This is in line with the report by Gressley and Armentano (2005), who found no effects of abomasal inulin infusion on ruminal $\mathrm{NH}_{3}$ concentrations or urinary excretion of purine derivatives.

Previous observations in lactating dairy cows point toward favoring urea-N transfer to the rumen over transfer to the distal segments by upregulating ruminal extraction of urea-N by 2.9- to 3.9-fold compared with PDV extraction (Kristensen et al., 2010; Røjen et al., 2011). This is in line with results of the present study, in which ruminal extraction of arterial urea- $\mathrm{N}$ was upregulated by 3.5- to 3.6-fold relative to portal extraction of arterial urea-N. Nevertheless, the observed increase in PDV extraction of arterial blood urea-N with the OLIGO treatment suggests that even though the absolute amounts of urea- $\mathrm{N}$ transfer were decreased with the OLIGO treatment, and the extraction of urea$\mathrm{N}$ across the rumen wall was unaffected by treatment, some upregulation of the permeability for urea- $\mathrm{N}$ across the PDV tissues was apparent, most likely the hindgut, when hindgut fermentation was increased by the infusion of oligofructose. In addition, a very pronounced postprandial decrease in ruminal urea- $\mathrm{N}$ extraction occurred in the first hours after feeding, which is in- 
dicative of a short-term regulatory mechanism affecting ruminal urea- $\mathrm{N}$ handling and thus supports previous findings (Røjen et al., 2011). Postprandial increases in ruminal $\mathrm{NH}_{3}$ concentration might have an inhibitory effect on the ruminal extraction of arterial urea-N on a relatively short-term basis.

\section{$\mathrm{NH}_{3}$ and VFA}

Blood urea-N might constitute a substantial source of $\mathrm{N}$ in the large intestine during increased carbohydrate fermentation; however, results of the present study suggest that oligofructose infused into the abomasum exerts a urea-N-lowering effect in the blood by another mechanism rather than an increase in the absolute amounts of urea- $\mathrm{N}$ transfer in the hindgut. The $\mathrm{NH}_{3}$ absorption to the portal vein was decreased by $97 \pm$ $25 \mathrm{mmol} / \mathrm{h}$ with the OLIGO treatment, equaling 136 $\mathrm{g}$ of $\mathrm{CP} / \mathrm{kg}$ of infused oligofructose. This value is quite similar to the ruminal microbial protein efficiencies suggested by Madsen (1985) and indicates that the reduction in arterial blood urea- $\mathrm{N}$ was caused by reduced $\mathrm{NH}_{3}$ absorption rather than increased urea- $\mathrm{N}$ recycling to the hindgut. Further, fecal $\mathrm{NH}_{3}$ concentration was substantially lower in the OLIGO treatment compared with the CTRL treatment (0.087 vs. $2.511 \mathrm{mM}$ ), which could be an indication that oligofructose is effective in promoting microbial proliferation in the hindgut, hence lowering $\mathrm{NH}_{3}$ absorption to the blood. Similarly, Younes et al. (2001), using arteriovenous differences across the cecum and cecal blood flow in rats adapted to a diet with $10 \%$ of oligofructose, found depressed cecal $\mathrm{NH}_{3}$ concentrations compared with a diet with $0 \%$ of oligofructose. However, increased cecal $\mathrm{NH}_{3}$ absorption was observed and was proposed to originate from increased cecal transfer of urea- $\mathrm{N}$, which in turn increased the ureolytic microbial activity, thus eliciting substantial cecal $\mathrm{NH}_{3}$ absorption. In that study, urea- $\mathrm{N}$ transfer to the cecum was generally greater than $\mathrm{NH}_{3}$ absorption. In the present study, regardless of treatment, $\mathrm{NH}_{3}$ absorption levels were substantial and approximately double those of urea-N transfer, thus showing the relative large importance of the rumen over the hindgut in ruminants.

The increased fecal molar proportion of butyrate did not lead to an increase in urea- $\mathrm{N}$ transfer. This contrasts with previous findings in rats, in which increased cecal VFA concentrations, especially of butyrate, which is considered a potent trophic factor for the cecum wall, resulted in enlargement of the exchange surface area between the blood and luminal fluid, and were proposed to partly explain a greater rate of urea-N transfer (Rémésy and Demigné, 1989; Younes et al., 2001). Similar effects on urea-N transfer into the ru- men have been observed in ruminants with long-term (2 wk) intraruminal infusions of butyrate (Norton et al., 1982), with the effects on urea-N transfer being ascribed to the effects of VFA on ruminal epithelial cell proliferation (Gálfi et al., 1991). In view of the fact that, in this study, total fecal VFA concentration was only numerically increased and molar proportions of all fecal VFA were decreased with the OLIGO treatment except butyrate, which indeed increased, it appears that the observed changes in fecal VFA did not affect the epithelial cell metabolism to a degree where urea-N transfer was increased. In addition, it is to be expected that differences between ruminants and monogastrics exist in the permeability to urea- $\mathrm{N}$ across the hindgut epithelia that are attributable to differences in digestive tract structure and colonic microflora. It is also worth mentioning, however, that the effect on glucogenic status with the OLIGO treatment likely imposed by the overall greater supply of butyrate relative to propionate caused decreased hepatic glucose release and circulating levels of glucose, as well as increased hepatic uptake of L-lactate. This may point in the direction of a more ketogenic metabolism in the OLIGO treatment.

\section{Increasing Hindgut Fermentation Shifts N Excretion from Urine to Feces}

In the present study, we observed a shift in $\mathrm{N}$ excretion from the renal to the intestinal site, without affecting total $\mathrm{N}$ balance (data not shown). This is a common observation when fermentable carbohydrate to the hindgut is increased (Surra et al., 1997; Propst et al., 2003; Gressley and Armentano, 2005). In addition, urea-N excretion was decreased relative to the CTRL treatment. This is presumably an effect of the observed decrease in hepatic urea- $\mathrm{N}$ production as well as the decreased level of circulating urea-N leading to less urea-N potentially destined for renal excretion. These findings corresponded with the observed decrease in diuresis and renal clearance of blood urea- $\mathrm{N}$ in the OLIGO treatment, and no change in renal plasma flow between treatments indicates that the change in urinary $\mathrm{N}$ excretion was mainly an effect of a decrease in the urea-N excretion with the OLIGO treatment. Similar changes were observed in lactating cows when decreasing the dietary $\mathrm{N}$ intake, causing a decrease in the ratio of urea-N to total urinary N (Gressley and Armentano, 2005; Røjen et al., 2011).

\section{CONCLUSIONS}

Abomasal infusion of oligofructose did not increase urea-N transfer from the blood to the gut in lactating dairy cows, and the decrease in arterial blood urea-N 
concentration could not be explained by an increased rate of urea- $\mathrm{N}$ removal from the blood. The reduction in arterial blood urea- $\mathrm{N}$ concentration, as well as in the urea- $\mathrm{N}$ concentration in milk, and urinary $\mathrm{N}$ excretion could be explained by reduced $\mathrm{NH}_{3}$ input to hepatic urea- $\mathrm{N}$ synthesis caused by increased sequestration of $\mathrm{NH}_{3}$ in the hindgut and excretion in the feces. Increasing the hindgut fermentation in lactating dairy cows by abomasal infusion of $1,500 \mathrm{~g} / \mathrm{d}$ of oligofructose can be used to shift $\mathrm{N}$ excretion from urine to feces without impairing rumen fermentation.

\section{ACKNOWLEDGMENTS}

We gratefully acknowledge Birgit H. Løth, Anne Krustrup, Pia Jensen, Marie Engbæk, Thorkild N. Jakobsen, Ole H. Olsen, Dagmara Lukaszek, and the barn staff at the Department of Animal Science, Aarhus University (Tjele, Denmark) for skillful technical assistance. Funding for the study was provided by the Commission of the European Communities (Brussels, Belgium; FP7, KBBE-2007-1), the Directorate for Food, Fisheries and Agri Business (Copenhagen, Denmark; 3304-VMP-05-005), and the Department of Animal Science, Aarhus University.

\section{REFERENCES}

AOAC. 1990. Official Methods of Analysis. 15th ed. AOAC, Gaithersburg, MD.

Bissell, H. A., and M. B. Hall. 2010. Cattle differ in ability to adapt to small intestinal digestion of starch. J. Dairy Sci. 93 (E-Suppl. 1):845. (Abstr.)

Bristow, A. W., D. C. Whitehead, and J. E. Cockburn. 1992. Nitrogenous constituents in the urine of cattle, sheep and goats. J. Sci. Food Agric. 59:387-394

Calsamiglia, S., A. Ferret, C. K. Reynolds, N. B. Kristensen, and A. M. Van Vuuren. 2010. Strategies for optimizing nitrogen use by ruminants. Animal 4:1184-1196.

Gálfi, P., S. Néogrady, and T. Sakata. 1991. Effects of volatile fatty acids on the epithelial cell proliferation of the digestive tract and its hormonal mediation. Pages 49-59 in Physiological Aspects of Digestion and Metabolism in Ruminants: Proceedings of the Seventh International Symposium on Ruminant Physiology. T. Tsuda, Y. Sasaki, and R. Kawashima, ed. Academic Press, San Diego, CA.

Gressley, T. F., and L. E. Armentano. 2005. Effects of abomasal pectin infusion on digestion and nitrogen balance in lactating dairy cows. J. Dairy Sci. 88:4028-4044.

Gressley, T. F., and L. E. Armentano. 2007. Effects of low rumen-degradable protein or abomasal fructan infusion on diet digestibility and urinary nitrogen excretion in lactating dairy cows. J. Dairy Sci. 90:1340-1353.

Gressley, T. F., M. B. Hall, and L. E. Armentano. 2011. Ruminant Nutrition Symposium: Productivity, digestion, and health responses to hindgut acidosis in ruminants. J. Anim. Sci. 89:1120-1130.

Harvey, R. B., and A. J. Brothers. 1962. Renal extraction of paraaminohippurate and creatinine measured by continuous in vivo sampling of arterial and renal-vein blood. Ann. N. Y. Acad. Sci. 102:46-54.

Hedemann, M. S., and K. E. B. Knudsen. 2010. Dried chicory root has minor effects on the digestibility of nutrients and the composition of the microflora at the terminal ileum and in faeces of growing pigs. Livest. Sci. 134:53-55.

Hesta, M., G. P. J. Janssens, J. Debraekeleer, and R. De Wilde. 2001. The effect of oligofructose and inulin on faecal characteristics and nutrient digestibility in healthy cats. J. Anim. Physiol. Anim. Nutr. (Berl.) 85:135-141.

Hume, I. D. 1997. Fermentation in the hindgut of mammals. Pages 84-115 in Gastrointestinal Microbiology. 1. Gastrointestinal Ecosystems and Fermentations. R. I. Mackie and B. A. White, ed. Chapman and Hall, New York, NY.

Kaur, N., and A. Gupta. 2002. Applications of inulin and oligofructose in health and nutrition. J. Biosci. 27:703-714

Kristensen, N. B., A. Danfær, V. Tetens, and N. Agergaard. 1996 Portal recovery of intraruminally infused short-chain fatty acids in sheep. Acta Agric. Scand. A Anim. Sci. 46:26-38.

Kristensen, N. B., J. V. Norgaard, S. Wamberg, M. Engbaek, J. A. Fernandez, H. D. Zacho, and H. D. Poulsen. 2009. Absorption and metabolism of benzoic acid in growing pigs. J. Anim. Sci. $87: 2815-2822$.

Kristensen, N. B., A. Storm, B. M. L. Raun, B. A. Røjen, and D. L. Harmon. 2007. Metabolism of silage alcohols in lactating dairy cows. J. Dairy Sci. 90:1364-1377.

Kristensen, N. B., A. C. Storm, and M. Larsen. 2010. Effect of dietary nitrogen content and intravenous urea infusion on ruminal and portal-drained visceral extraction of arterial urea in lactating Holstein cows. J. Dairy Sci. 93:2670-2683.

Lapierre, H., and G. E. Lobley. 2001. Nitrogen recycling in the ruminant: A review. J. Dairy Sci. 84(E. Suppl.):E223-E236.

Larsen, M., and N. B. Kristensen. 2009. Effect of abomasal glucose infusion on splanchnic and whole-body glucose metabolism in periparturient dairy cows. J. Dairy Sci. 92:1071-1083.

Levrat, M. A., C. Rémésy, and C. Demigné. 1993. Influence of inulin on urea and ammonia nitrogen fluxes in the rat cecum: Consequences on nitrogen excretion. J. Nutr. Biochem. 4:351-356.

Madsen, J. 1985. The basis for the proposed Nordic protein evaluation system for ruminants: The AAT-PBV system. Acta Agric. Scand. 25(Suppl.):9-20.

Marsh, W. H., B. Fingerhut, and H. Miller. 1965. Automated and manual direct methods for the determination of blood urea. Clin. Chem. 11:624-627.

Milinovich, G. J., D. J. Trott, P. C. Burrell, A. W. Van Eps, M. B. Thoefner, L. L. Blackall, R. A. M. Al Jassim, J. M. Morton, and C. C. Pollitt. 2006. Changes in equine hindgut bacterial populations during oligofructose-induced laminitis. Environ. Microbiol. 8:885-898.

Norton, B. W., A. N. Janes, and D. G. Armstrong. 1982. The effects of intraruminal infusions of sodium bicarbonate, ammonium chloride and sodium butyrate on urea metabolism in sheep. Br. J. Nutr. $48: 265-274$.

Ørskov, E. R., C. Fraser, V. C. Mason, and S. O. Mann. 1970. Influence of starch digestion in the large intestine of sheep on caecal fermentation, caecal microflora and faecal nitrogen excretion. Br. J. Nutr. 24:671-682.

Plaizier, J. C., D. O. Krause, G. N. Gozho, and B. W. McBride. 2008. Subacute ruminal acidosis in dairy cows: The physiological causes, incidence and consequences. Vet. J. 176:21-31.

Propst, E. L., E. A. Flickinger, L. L. Bauer, N. R. Merchen, and G. C. Fahey. 2003. A dose-response experiment evaluating the effects of oligofructose and inulin on nutrient digestibility, stool quality, and fecal protein catabolites in healthy adult dogs. J. Anim. Sci. 81:3057-3066

Rémésy, C., and C. Demigné. 1989. Specific effects of fermentable carbohydrates on blood urea flux and ammonia absorption in the rat cecum. J. Nutr. 119:560-565.

Reynolds, C. K. 2002. Economics of visceral energy metabolism in ruminants: Toll keeping or internal revenue service? J. Anim. Sci. 80(E. Suppl. 2):E74-E84.

Reynolds, C. K., S. B. Cammell, D. J. Humphries, D. E. Beever, J. D. Sutton, and J. R. Newbold. 2001. Effects of postrumen starch infusion on milk production and energy metabolism in dairy cows. J. Dairy Sci. 84:2250-2259. 
Roberfroid, M. B., and N. M. Delzenne. 1998. Dietary fructans. Annu. Rev. Nutr. 18:117-143.

Røjen, B. A., and N. B. Kristensen. 2012. Effect of time duration of ruminal urea infusions on ruminal ammonia concentrations and portal-drained visceral extraction of arterial urea-N in lactating Holstein cows. J. Dairy Sci. 95:1395-1409.

Røjen, B. A., P. K. Theil, and N. B. Kristensen. 2011. Effects of nitrogen supply on inter-organ fluxes of urea-N and renal urea-N kinetics in lactating dairy cows. J. Dairy Sci. 94:2532-2544.

Schürch, A. F., L. E. Lloyd, and E. W. Crampton. 1950. The use of chromic oxide as an index for determining the digestibility of a diet. J. Nutr. 41:629-636.

Sjaunja, L. O., L. Bævre, L. Junkkarinen, J. Pedersen, and J. Setälä 1991. A Nordic proposal for an energy corrected milk (ECM) formula. Pages 156-157 in Proc. 27th Session of Int. Comm. for Recording Productivity of Milk Animals (ICRPMA). Eur. Assoc. Anim. Prod. Publ. 50. Eur. Assoc. Anim. Prod., Wageningen, the Netherlands.

Surra, J. C., J. A. Guada, J. Balcells, and C. Castrillo. 1997. Effects of post-ruminal fermentation on the faecal and urinary excretion of purines. Anim. Sci. 65:383-390.

Theurer, C. B., G. B. Huntington, J. T. Huber, R. S. Swingle, and J. A. Moore. 2002. Net absorption and utilization of nitrogenous compounds across ruminal, intestinal, and hepatic tissues of growing beef steers fed dry-rolled or steam-flaked sorghum grain. J. Anim. Sci. 80:525-532.

Thornton, R. F., P. R. Bird, M. Somers, and R. J. Moir. 1970. Urea excretion in ruminants. III. The role of the hind-gut (caecum and colon). Aust. J. Agric. Res. 21:345-354.

Volden, H., ed. 2011. NorFor-The Nordic feed evaluation system. Eur. Assoc. Anim. Prod. Publ. 130. Wageningen Academic Publishers, Wageningen, the Netherlands.

Wolin, M. J. 1981. Fermentation in the rumen and human large intestine. Science 213:1463-1468.

Younes, H., J. C. Alphonse, S. R. Behr, C. Demigné, and C. Rémésy. 1999. Role of fermentable carbohydrate supplements with a lowprotein diet in the course of chronic renal failure: Experimental bases. Am. J. Kidney Dis. 33:633-646.

Younes, H., J. C. Alphonse, M. Hadj-Abdelkader, and C. Rémésy. 2001. Fermentable carbohydrate and digestive nitrogen excretion. J. Ren. Nutr. 11:139-148.

Younes, H., N. Egret, M. Hadj-Abdelkader, C. Rémésy, C. Demigné, C. Gueret, P. Deteix, and J. C. Alphonse. 2006. Fermentable carbohydrate supplementation alters nitrogen excretion in chronic renal failure. J. Ren. Nutr. 16:67-74 